\title{
Investigation of Smartphone Addiction Effect on Recreational and Physical Activity and Educational Success
}

\author{
Osman Gumusgul ${ }^{1, *}$ \\ ${ }^{1}$ Faculty of Sport Sciences, Suleyman Demirel University, Isparta, Turkey \\ *Correspondence: Faculty of Sport Sciences, Suleyman Demirel University, Isparta, Turkey. Tel: 90-246-211-4759. \\ E-mail: osmangumusgul@gmail.com
}

Received: June 12, 2018

Accepted: July 3, 2018 Online Published: July 23, 2018

doi:10.5430/wje.v8n4p11

URL: https://doi.org/10.5430/wje.v8n4p11

\begin{abstract}
The aim of the study was to investigate smartphone addiction effect on physical activity, recreational sports participation and educational success. In total, 255 students studying at Dumlupinar University and using smartphone (136 male and 119 female) voluntarily participated to the study. Within the scope of this study, Smartphone Addiction Scale-Short Version (SAS-SV) (Noyan, Darcin, Nurmedov, Yilmaz \& Dilbaz, 2015) was applied to the participants. To the data gathered from the participants, parametric tests as Independent Sample T-Test and ANOVA were applied $(p<0.05)$. According to the results there is significant difference between smartphone addiction of participants and gender, age and recreational sports $(\mathrm{p}<0,05)$; but there is no significant difference between smartphone addiction and academic success and recreational activities practiced $(p>0,05)$. It is considered that participants with higher academic grades may have higher smartphone addiction score because of using smartphones as teaching tool in classrooms. Participants practicing physical and recreational sports have less smartphone addiction score and it can give a clue that smartphones are constraints for physical activities and this may be a reason and taking precaution subject for a sedentary lifestyle and unhealthy individuals.
\end{abstract}

Keywords: smartphone addiction, recreation, physical activity, education, educational success

\section{Introduction}

Many physical activity and leisure constraints have come into existence for human beings in daily life (Demirel, et al., 2017; Polat, 2017). Formerly physical activity and leisure constraints could mainly be determined as individual psychology, lack of social environment and knowledge, lack of interest and friends, facilities, services and time (Carroll \& Alexandris, 1997; Acet, Yucel, Ersoy \& Akkoyunlu, 2012; Ekinci, Kalkavan, Ustun \& Gunduz, 2014; Demirel, Isik, Ustun \& Gumusgul, 2016) but with technologic development physical activity and leisure constraints have mutated as well. Using them too often in daily life, smartphones are one of the biggest physical activity and leisure constraints recently. With 4,48 hours daily average use of smartphone users the most smartphone addicted country on the world-wide is Brazil according to Statista's research. Brazil is followed by China with 3.03 hours, the United States with 2.37 hours and Italy with 2.34 hours. (Haberturk News). Lack of physical activity is the fourth most common risk factor for death in the world, and 3.2 million people die each year due to illnesses caused by inactivity (Cinaz, 2014).

The use of the internet, which was formerly only accessed with computers, now is accessible with smartphones as well (Yücelten, 2016). With development of technology and new applications, the use of smartphones is increasing day by day and making people addicted. Especially with fast development and accessibility of internet and smartphones, they add a lot of positive and negative things to lives.

Addiction is currently defined as a behavior over which an individual has impaired control with harmful consequences (Cottler, 1993; Rounsaville, Bryant, Babor, Kranzlar \& Kadden, 1993). Psychology, which is a branch of psychology from mobile phone addiction, has added a new phobia. Nomophobia, derived from the English "no mobile phobia", is anxious to remain in the cell phone (Dirik, 2016). Smart phone addiction is questionable as a function of biological binding and nervous system to a number of substances such as smoking, drugs and alcohol (Comings, 1995). 
Analysing many studies recently, quite a few studies inlclude smartphone addiction and these studies have pointed smartphone addiction according to different variables. Some of these studies focus on smartphone effects (Toda et al, 2006) and the relationship between smartphone addiction and estimated hypothesized psychological factors (Beranuy, Oberst, Carbonell \& Charmarro, 2009; Bianchi \& Phillips, 2005; Ehrenberg, Juckes, White \& Walsh, 2008; Ezoe et al., 2009; Ha, Chin, Park, Ryu \& Yu, 2008; Hong, Chiu \& Huang, 2012; Walsh, White, Cox \& Young, 2011), social effecting factors (Walsh et al., 2011), mobile phone usage behavior (Billieux, Linden, \& Rochat, 2008; Hong et al., 2012; Walsh et al., 2011) and family environmental factors (Toda et al., 2008). In the study conducted by Sevi, Odabasioglu, Genc, Soykal \& Ozturk (2014), it was found that the increase in mobile phone usage was mostly related to self-insecurity, social incompatibility, frequent morale, and anxiety. Moreover, overuse of mobile phone has been associated with passive - aggressive personality disorder, obsessive, schizoid, borderline features and hypomania. It has also been found that increased need for mobile phones is also associated with antisocial tendencies. Lee (2006) found a negative relationship between shyness and mobile phone usage and mobile usage motivation. Also, the presence of applications that allow text messages on the smartphone causes shy people to prefer written applications rather than face-to-face communication. In addition, the internet on smartphones is able to isolate shy people from situations where they are uncomfortable with applications such as games. According to Bian and Leung (2015), shy individuals are more prone to smartphone addiction. It has been seen that people with low self-esteem overuse mobile phones and use mobile phones to increase their low self-esteem (Phillips, Ogeil \& Blaszczynski, 2011).

In educational part, smartphones can be a source of great disruption in workplaces and classrooms, as they provide individuals with access to texting, games, social media and internet. Given these features, mobile phones have the potential to reduce the attention students pay to classes and can therefore be detrimental to learning (Beland \& Murphy, 2015). There are debates in many countries as to how schools should address the issue of mobile phones. Some advocate for a complete ban while others promote the use of mobile phones as a teaching tool in classrooms (Sandoval, Dale \& Reuven, 2015).

In this case, this study aims to figure out smartphone addiction effect on physical activity, recreational sports participation and educational success.

\section{Method}

\subsection{Design of the Study}

In the present study, cross-sectional method has beed applied as study design. According to this method, first, data was collected from the sampling group in order to identify relationships between the patterns and then generalized back to the population (Ustun, 2018).

\subsection{Sample of the Study}

The sample of the research was 255 university students voluntarily participated to the study (136 male, 119 female) studying in Dumlupinar University School of Physical Education and Sports.

\subsection{Data Collection Tool}

Within the scope of this study, Smartphone Addiction Scale (SAS), developed by Kwon et al. (2013) and translated to Turkish Language by Noyan et al. (2015), was applied to participants.

\subsection{Analysis of the Data}

The data gathered from the participants was evaluated with the statistics package program SPSS 22.0. First of all, Cronbach Alpha was figured out as $.881(\mathrm{~N}=10)$. According to Skewness $(0,044)$ and Kurtosis $(-0,385)$ values data had normal distribution according to the acceptable range for skewness or kurtosis below +1.5 and above -1.5 (Tabachnick \& Fidell, 2013). Parametric tests as Independent Sample T-Test and One Way ANOVA were performed depending on this result $(\mathrm{p}<0.05)$. 
Table 1. Demographic Features of Participants

\begin{tabular}{llll}
\hline Factor & Variable & $\mathbf{N}$ & $\mathbf{\%}$ \\
\hline Gender & Male & 136 & 53,3 \\
Age & Female & 119 & 46,7 \\
& 20 years old and younger & 12 & 23,1 \\
& $21-23$ years old & 59 & 54,5 \\
Free Time Activity & 24 years old and older & 139 & 22,4 \\
& Indoor Activities & 100 & 39,2 \\
& Physical Activities & 65 & 25,5 \\
& Cultural-Arts- Social Activities & 43 & 16,9 \\
& Outdoor Activities & 32 & 12,5 \\
Practicing Recreational Sports or Not & Touristic Activities & 15 & 5,9 \\
& Yes & 102 & 40 \\
Daily Smartphone Use & No & 153 & 60 \\
& Less than an hour & 15 & 5,9 \\
& Up to 2 hours & 67 & 26,3 \\
Intended Smartphone Use & 3-4 hours & 92 & 36,1 \\
& 5 hours and more & 81 & 31,8 \\
& Taking Photos & 12 & 4,7 \\
& SMS & 53 & 20,8 \\
& Web-searching & 79 & 31 \\
& E-mail & 11 & 4,3 \\
& Social Networks & 84 & 32,9 \\
\hline
\end{tabular}

\section{Results}

Table 2. T- Test Results According to Gender

\begin{tabular}{lllllll}
\hline & Gender & N & Mean & St. D. & t & p \\
\hline Smart Phone Addiction & Male & 136 & 27,97 & 11,00 & \multirow{2}{*}{0,40} & \multirow{2}{*}{0,00} \\
& Female & 119 & 33,16 & 10,10 & & \\
\hline
\end{tabular}

$* \mathrm{p}<0,05$

Significant differences of smartphone addiction scores related to gender variable has been determined in favour of female participants in Table-2 $(\mathrm{t}=0,40 ; \mathrm{p}<0.05)$.

Table 3. Anova Results According to Age

\begin{tabular}{llrlllll}
\hline & Age & N & Mean & St. D. & f & p & Tukey \\
\hline \multirow{2}{*}{ Smart Phone } & 20 years old and younger & 59 & 34,15 & 11,21 & & & $* 1-2$ \\
Addiction & 21-23 years old & 139 & 29,28 & 11,12 & 4,70 & 0,01 & $* 1-3$ \\
& 24 years old and older & 57 & 29,22 & 9,11 & & & \\
\hline
\end{tabular}

$* \mathrm{p}<0,05$

As a result of the variance analysis which has been performed to find out differences of smartphone addiction scores related age variable, statistically significant difference has been found $[F(2-254)=4,701 ; p<0,05]$. According to Tukey test, significant difference is between the participants who are 20 years old and younger and other groups $(\mathrm{p}<0,05)$.

Table 4. T- Test Results According to Practicing Recreational Sports or Not

\begin{tabular}{lllllll}
\hline & Recreational Sports & N & Mean & St. D. & t & p \\
\hline Smart Phone Addiction & Yes & 102 & 28,27 & 11,47 & \multirow{2}{*}{2,57} & \multirow{2}{*}{0,01} \\
& No & 153 & 31,81 & 10,27 & & \\
\hline
\end{tabular}

$* \mathrm{p}<0,05$ 
Significant differences on smartphone addiction points related to practicing recreational sports or not variable has been determined in favor of group not practicing any recreational sports in Table $4(t=-2,57 ; p<0.05)$.

Table 5. Anova Results According to Practicing Recreational Sport Type

\begin{tabular}{lllllll}
\hline & Recreational Activities Practiced & N & Mean & St. D. & f & p \\
\hline & Indoor Activities & 100 & 30,41 & 10,20 & & \\
& Physical Activities & 65 & 30,09 & 12,57 & & \\
SmartPhone Addiction & Cultural-Arts-Social Activities & 43 & 30,34 & 9,67 & 0,38 & 0,82 \\
& Outdoor Activities & 32 & 32,12 & 10,42 & & \\
& Touristic Activities & 15 & 28,06 & 12,56 & & \\
\hline
\end{tabular}

$* \mathrm{p}<0,05$

According to the variance analysis which has been performed to find the differences on the smartphone addiction points related to recreational activities variable, statistically no significant difference has been found $[\mathrm{F}(4-254)=$ $0,382 ; \mathrm{p}>0,05]$.

Table 6. T-test Results According to Academic Success (on 4,00)

\begin{tabular}{lllllll}
\hline & Academic Grade & N & Mean & St. D. & t & p \\
\hline Smart Phone Addiction & 3,00 and less & 182 & 29,80 & 11,43 & \multirow{2}{*}{$-1,49$} & \multirow{2}{*}{0,13} \\
& $3,01-4,00$ & 73 & 31,86 & 9,29 & & \\
\hline
\end{tabular}

$* \mathrm{p}<0,05$

According to T-test results related to academic success variable statistically no significant difference has been determined $(\mathrm{t}=-1,49 ; \mathrm{p}>0,05)$.

\section{Discussion}

According to the results there is significant difference between smartphone addiction of participants and gender, age and recreational sports but there is no significant difference on academic success and recreational activities practiced. Noyan et al. (2015) emphasizes that smartphone addicted male participants should have more than 31 and addicted female participants should have more than 33 total scores. In our study female participants have 33,16 points. This result indicates that female university students spend much more time with smartphones, they prefer spending free time with mobiles and it can be counted as leisure and physical activity constraints for them. Supporting this result of the study, Gezgin, Sumuer, Arslan \& Yildirim (2017) found that there is significant difference between females' and male's nomophobia levels and female pre-service teachers' nomophobia levels are higher than males.

One Way Anova was applied applied to determine whether there was statistically meaningful difference between participants' smartphone addiction scores and age variable. Tukey test reveals that 20 years old and younger participants cause statistically significant difference. Applications for smartphones aim mostly younger users and this can cause younger university students using smartphones have higher scores than older students. On the contrary, Yildirim C., Sumuer, Adnan \& Yildirim S. (2015) and Adnan \& Gezgin (2016) found no significant difference between nomophobia and age variable on their studies.

University students practicing recreational sports have fewer score than the ones not practicing any recreational sports. It can give a clue that smartphones are constraints for physical activities and this may be a reason for a sedentary lifestyle and unhealthy individuals. On the other hand, Yalcin, Demirel M., Demirel D. \& Colakoglu (2017) has found that there is significant relation between participating free time activities and smartphone addiction with consideration of students tend to use smartphones as an effective means of communication in achieving the results they desire and to show these results to their friends and increase their self-esteem with motivational factors such as appreciation, a and fame in social platforms and reaching free time and satisfaction levels. The other result of the study points that whichever recreational activity individuals participate, makes statistically no difference and all scores are few to be smartphone addicted.

T-test was applied to examine whether there was statistically meaningful difference between participants' smartphone addiction scores and academic success and statistically no significant difference has been determined. There are different studies in literature examining effect of using smartphones and on students' academic performance and 
academic success (Hong et al., 2012; Akilli \& Gezgin, 2016). All these studies state that students who are affected by the nomophobia are experiencing sleeping problems and are skeptical about motivating even their daily work aside from academic studies. This situation also affects the educational life of the students. It is thought these results may lead to a decrease in the cognitive performance of learners and also in the yield and quality of the learners, and difficulty in remembering.

\section{Conclusion}

In consideration of all these results, in accordance with the respective regulations, it is necessary for teachers and students to be informed about this issue by considering the positive or negative relationship between students' smartphone addiction and their academic success. Standardization of students' use of smartphones should be assessed as a necessity to encourage the use of smartphone technology if it is to be used as a support to learn the use of smartphone technology.

\section{Acknowledgements}

An earlier version of this study was presented in World Congress of Sport Sciences Researches, 23-26 November 2017, Manisa, Turkey.

\section{References}

Acet, M., Yücel, A. S., Ersoy, A., \& Akkoyunlu, Y. (2012). Examining some of parameters using internet and gratification motivation of the students of the Dumlupinar University. UHBAB International Refereed Journal of Humanities and Academic Sciences, 1(1), 118-141. https://doi.org/10.17368/UHBAB.2012018731

Adnan, M., \& Gezgin, D. M. (2016). A modern phobia: Prevalence of nomophobia among college students. Ankara University Journal of Faculty of Educational Sciences, 49(1), 141-158.

Akilli, G. K., \& Gezgin, D. M. (2016). Examination of the relationship between nomophobia levels and different behavior patterns of university students. Mehmet Akif Ersoy University Journal of Education Sciences, 1(40), 51-69.

Beland, L.P., \& Murphy, R. (2015). III Communication: technology, distraction \& student performance. London: Centre for Economic Performance, The London School of Economics and Political Science.

Beranuy, M., Oberst, U., Carbonell, X., \& Charmarro, A. (2009). Problematic internet and mobile phone use and clinical symptoms in college students: The role of emotional intelligence. Computers in Human Behaviour, 25(5), 1182-1187. https://doi.org/10.1016/j.chb.2009.03.001

Bian, M., \& Leung, L. (2015). Linking loneliness, shyness, smartphone addiction symptoms, and patterns of smartphone use to social capital. Social Science Computer Review, 33(1), 61-79. https://doi.org/10.1177/0894439314528779

Bianchi, A., \& Phillips, J. G. (2005). Psychological predictors of problem mobile phone use. Cyber Psychology \& Behavior, 8(1), 39-51. https://doi.org/10.1089/cpb.2005.8.39

Billieux J., Van der Linden M., \& Rochat, L. (2008). The role of impulsivity in actual and problematic use of the mobile phone. Applied Cognitive Psychology, 22, 1195-1210. http://dx.doi.org/10.1002/acp.1429

Carroll, B., \& Alexandris, K. (1997). Perception of constraints in strength of motivation: Their relationship to recreational sport participation in Greece. Journal of Leisure Research, 29(3), 279. https://doi.org/10.1080/00222216.1997.11949797

Cinaz, B., \& Arnrich, B. (2014). Assessing lifestyle parameters using smartphones. XVI. Academic Informations Conference Reports. 5 - 7 Feb. 2014 Mersin: Mersin University.

Comings, E. D. (1995). Tourette's syndrome: A behavioral spectrum disorder. behavioral neurology of movement disorders. New York: Raven Press.

Cottler, L. B. (1993). Comparing DSM-III-R and ICD-10 substance use disorders. Addiction, 88, 689- 696. https://doi.org/10.1111/j.1360-0443.1993.tb02082.x

Demirel, M., Harmandar Demirel, D., \& Serdar, E. (2017). Constraints and perceived freedom levels in the leisure of university students. Journal of Human Sciences, 14(1), 789-795. https://doi.org/10.14687/jhs.v14i1.4340 
Demirel, M., Işık, U., Demirel, D. H., Üstün, Ü. D., \& Gümüşgül, O. (2016). Future time perception: A study on School of Physical Education and Sports Students. Journal of Sport Sciences, 6(1), 10-20.

Dirik, K. (2016). The relationship between the self confidence levels of the adolescents' and smart phone addiction. Master Thesis, Gelisim University, Istanbul.

Ehrenberg, A., Juckes, S., White, K. M., \& Walsh, S. P. (2008). Personality and selfesteem as predictors of young people's technology use. CyberPsychology \& Behavior, 11(6), 739-741. https://doi.org/10.1089/cpb.2008.0030

Ekinci, N.E., Kalkavan, A., Üstün, Ü. D., \& Gündüz, B. (2014). Investigation of factors that may constrain participation of sportive and non sportive recreational activities among university students. Sportive Sight: Journal of Sport and Education, 1(1), 1-13.

Ezoe, S., Toda, M., Yoshimura, K., Naritomi, A., Den, R., \& Morimoto, K. (2009). Relationships of personality and lifestyle with mobile phone dependence among female nursing students. Social Behavior and Personality: An International Journal, 37(2), 231-238. https://doi.org/10.2224/sbp.2009.37.2.231

Gezgin, D.M., Sumuer, E., Arslan, O., \& Yıldırım, S. (2017). Nomophobia prevalence among pre-service teachers: A case of Trakya University. Trakya University Journal of Education Faculty, 7(1), 86-95.

Ha, J. H., Chin, B., Park, D. H., Ryu, S. H., \& Yu, J. (2008). Characteristics of excessive cellular phone use in Korean adolescents. CyberPsychology \& Behavior, 11(6), 783-784. https://doi.org/10.1089/cpb.2008.0096

Haberturk News: http://www.haberturk.tv/teknoloji/haber/1512003-akilli-telefon-bagimlisi-ulkeler/2. (31.03.2018).

Hong, F. Y., Chiu, S. I., \& Huang, D. H. (2012). A model of the relationship between psychological characteristics, smartphone addiction and use of mobile phones by Taiwanese female university students. Computer in Human Behavior, 28(6), 2152-2159. https://doi.org/10.1016/j.chb.2012.06.020

Kwon, M., Lee J.Y., Won W.Y., Park J.W., Min J.A., Hahn J., Gu, X., Choi, J.H., \& Kim, D.J. (2013). Development and Validation of a Smartphone Addiction Scale (SAS). Plos One, 8(2), e56936. https://doi.org/10.1371/journal.pone.0056936

Lee, Y. S. (2006). Biological model and pharmacotherapy in internet addiction. Journal of the Korean Medical Association, 49(3), 209-214. https://doi.org/10.5124/jkma.2006.49.3.209

Noyan, C.O., Darcin A.E., Nurmedov, S., Yılmaz, O., \& Dilbaz, N. (2015). Validity and reliability of the Turkish version of the smartphone addiction scale-short version among university students. Anatolian Journal of Psychiatry, 16(Special issue.1), 73-81. https://doi.org/10.5455/apd.176101

Polat, C. (2017). Examination of leisure constraints of university students according to some variables. Master Thesis. Dumlupinar University, Kutahya.

Rounsaville, B.J., Bryant, K., Babor, T., Kranzler, H., \& Kadden, R. (1993). Cross system agreement for substance use disorders: DSM-III-R, DSM-IV and ICD-10, Addiction, 88, 337-348. https://doi.org/10.1111/j.1360-0443.1993.tb00821.x

Sandoval, E., Dale E., \& Reuven B. (2015). Department of Education lifts ban on cell phones in New York City schools. New York Daily News.

Sevi, M. O., Odabasiioglu, G., Genc, Y., Soykal, I., \& Oztürk, O. (2014). Mobile Phone Survey: Standardization and examination of relation with personality characteristics. Journal of Addiction, 15(1), 15-22.

Tabachnick, B.G., \& Fidell, L.S. (2013). Using multivariate statistics (6th ed.). Boston: Pearson.

Toda, M., Ezoe, S., Nishi, A., Mukai, T., Goto, M., \& Morimoto, K. (2008). Mobile phone dependence of female students and perceived parental rearing attitudes. Social Behavior and Personality: An International Journal, 36(6), 765-770. https://doi.org/10.2224/sbp.2008.36.6.765

Toda, M., Monden, K., Kubo, K., \& Morimoto, K. (2006). Mobile phone dependence and health-related lifestyle of university students. Social Behavior and Personality: An International Journal, 34(10), 1277-1284. https://doi.org/10.2224/sbp.2006.34.10.1277

Ustun, U.D. (2018). Participation motivation in university students who engage in different team sports. World Journal of Education, 8(3), 12-17. https://doi.org/10.5430/wje.v8n3p12

Walsh, S. P., White, K. M., Cox, S., \& Young, R. Mc. D. (2011). Keeping in constant touch: The predictors of young Australians' mobile phone involvement. Computers in Human Behavior, 27(1), 333-342. 
https://doi.org/10.1016/j.chb.2010.08.011

Yalcin, C., Demirel, M., Demirel, D. H., \& Colakoglu, T. (2017). Investigation of opinions about meaning of leisure and smartphone addiction to physical education and sports students. IU Journal of Sport Sciences, 7(1), 1403-1414.

Yildirim, C., Sumuer, E., Adnan, M., \& Yildirim, S. (2015). A growing fear: Prevalence of nomophobia among Turkish college students. Information Development, $32(5), \quad 1322-1331$. https://doi.org/10.1177/0266666915599025

Yücelten, E. (2016). The analyze of the relation between attachment styles and undergraduate student addictions of internet and smartphones. Master Thesis, Uskudar University, Istanbul. 